\title{
EFFECTS OF MILLING ON THE BRAN REMOVAL, NUTRITIONAL AND COOKING CHARACTERISTICS OF TRADITIONAL RICE CULTIVARS
}

\author{
Farhan Mohiuddin. Bhat, Charanjit Singh Riar \\ Department of Food Engineering and Technology, \\ Sant Longowal Institute of Engineering and Technology, Longowal, Punjab, 148106, India \\ Sangita Sood \\ Department of Food science, Nutrition and Technology, \\ CSKHPKV, Palampur, HP. 176062
}

\begin{abstract}
The percentage of bran removed from the rice cultivars in the time interval of 0 to $30 \mathrm{~s}$ showed sharp slope, but the slope was less after this time duration (3060s). The rice cultivar Koshkari exhibited the highest percentage of bran removal at each milling interval of $10 \mathrm{~s}$ due to greater thickness of its rice kernels. The percentage of protein with milling duration depicted negative correlation, which indicated higher protein content could be retained by lowering the time period of milling. The difference in fat percentage with milling time from 0 to $60 \mathrm{~s}$ was found higher in Mushki Budgi (1.15\%) and lowest in Koshkari $(0.53 \%)$. The carbohydrate content of these rice cultivars at each successive stage of milling were found to increase with Mushki budgi depicted the highest rise in percentage in carbohydrate content $(3.61 \%)$ after 60s milling. The greater loss in ash content with increasing the degree of milling was found in Mushki budgi (94.73\%). The elongation ratio of the experimental rice cultivars were found to increase at each successive stage of milling interval. The increase in solids loss at each milling stage could be due to bursting of the rice kernels upon cooking, as the increase in carbohydrate content at each successive milling stage resulted in greater absorption of water. Keeping in view all the health related benefits associated with brown rice, the research focus on the optimum time required for milling rice, so that the cooking quality of rice kernels would be best along with its nutritional characteristics.
\end{abstract}

Key words: Rice cultivars; Milling time; bran; Nutritional composition; cooking characteristics.

\section{INTRODUCTION}

Rice is one of the major sources of staple food throughout the world and about $80 \%$ of rice production comes from the cultivation of Asian rice (Oryza sativa L). the brown rice hulled from paddy consists of 6-7\% bran layer, 2-3\% embryo and $90 \%$ endosperm [1]. The nutrients like proteins, lipids, dietary fibres, vitamins and minerals are mainly present in the germ and bran layers of the rice grains [2]. The fractions containing these valuable nutrients are removed from brown rice during milling operation for production of white rice. Rice with different degrees of bran removal is preferred in different markets due to varying colour of rice that is an important parameter of sensory perception. The market demand for whiter rice that has been milled properly to ensure complete bran removal is more than unmilled rice [3]. Milling of rice is done commercially to improve the physical and sensory properties of the rice grain and to increase its storage stability [4].

The physical properties of rice grains such as grain thickness has an important role in determining the cooking and texture attributes associated with rice grains, because rice grain with more thickness tends to have higher milling degree, lesser amylose content and higher cooking duration. The knowledge of physical characteristics of paddy grains is essential for the modelling of dynamic abrasion systems in rice milling operation and for the determination of physical properties including dimension characteristics and the quality parameters associated with milled rice will enhance the regular monitoring of milling operation in an objective manner so that it could be visualised very quickly within a short span of time to indicate any change in the properties of final product [5]. The physical properties of an agricultural product after harvesting determine its marketing value. The percentage 


\section{International Journal of Engineering Applied Sciences and Technology, 2019 Vol. 4, Issue 3, ISSN No. 2455-2143, Pages 294-301 \\ Published Online July 2019 in IJEAST (http://www.ijeast.com)}

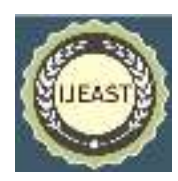

of whole grain is considered one of the most important parameter in the rice processing industry [6]. The cooking characteristics associated with rice grains have been found to be depended upon its amylose content, alkali spreading value, water uptake ratio, solids in gruel loss, volume expansion ratio and kernel elongation ratio. The quality of the grains includes a combination of different types of characters that in turn are found to exhibit any one quality attribute desirable to the consumers [7].

The purpose of the research was to study the effect of milling time from 0 to 60 seconds with interval of 10 seconds on the percentage of bran removal, nutritional composition and cooking characteristics of Traditional Pigmented and aromatic rice cultivars.

\section{Materials and methods}

\subsection{Chemicals and reagents}

All the chemicals and reagents used for analysis were of analytical grade and were procured from Standard Instruments Corporation Pvt. Ltd, Patiala (India) and Merck Chemical Private Limited (Shiv Sagar Estate A. Worli Mumbai400018).

\subsection{Experimental materials}

The paddy cultivars used for analysis of milling characteristics are traditional cultivars grown in Kashmir valley of $\mathrm{J} \& \mathrm{~K}$. These cultivars included the aromatic Mushki Kandi and Mushki Budij. the red colored cultivars consists of Zag and Shalle Keau, while Tilla Zag are the sparsely colored red colored cultivars with red rice kernels dispersed in many white colored cultivars. Koshkari is the non-pigmented and nonaromatic cultivars while the black colored rice cultivar included Kaw Kareed. The paddy cultivars were procured from state sponsored different breeding stations to ensure the purity of the particular strain.

\subsection{Dehusking and milling}

The paddy samples were manually cleaned to remove field impurities such as dust, dirt, stones, straw, small broken and immature kernels. The paddy samples were dried to $12 \%$ moisture content for optimum yield without much breakage when subjected to milling using lab de-husker (Make: Indosaw Ambala). The brown rice was milled in a pilot scale grinding mill (Agrosa India, Pvt. Ltd) powered by $0.5 \mathrm{hp}$, single phase motor, and consisting of a rotating emery coated disk and stationery steel casing. $100 \mathrm{~g}$ of brown rice was charged through the hopper and kept for 10 seconds in the action zone and passed through 100 mesh sieve to get the flour. Rice bran was obtained from the brown and pigmented rice cultivars (procured from different breeding centres of Kashmir valley) by milling the grains in a pilot scale grinding mill, where the bran was removed from the rice kernels by abrasive action of the emery roller followed by sieving to recover the bran. The rice flour was stored at $4{ }^{\circ} \mathrm{C}$ in air tight containers for further analysis.

\subsection{Proximate Composition}

Determinations of the proximate composition were done based on AOAC [8] standard method. The fat was determined by Soxhlet extraction method, and protein content was evaluated by the Kjeldahl method, using 5.8 as conversion factor. The ash content of the samples was determined by using muffle furnace at temperature of $550^{\circ} \mathrm{C}$.

\subsection{Elongation ratio}

The elongation ratio of the rice cultivars were measured by dividing the length of cooked rice kernels by length of uncooked rice samples. Results were reported as elongation ratio.

\subsection{Solids in gruel loss}

The solids in gruel loss was determined by calculating the total solids left after drying gruel obtained from rice cooked (up to $2 \mathrm{~g}$ in $20 \mathrm{ml}$ distilled water) during minimum cooking time. The aliquot of cooking water (gruel) was poured in a petriplate and the gruel was dried in a petriplate to complete dryness in hot air oven at $110^{\circ} \mathrm{C}$. The weight of the empty petriplate $\left(\mathrm{W}_{1}\right)$ and petriplate with dried gruel $\left(\mathrm{W}_{2}\right)$ was recorded and the solid in gruel loss was calculated as:

$\mathrm{W}_{2}-\mathrm{W}_{1}$; where $\mathrm{W}_{1}=$ weight of empty Petri-dish, $\mathrm{W}_{2}=$ weight of empty petri-dishes + dry gruel.

\subsection{Statistical Analysis}

All the experiments were carried out in triplicates. The data were analyzed by using statistical software (statistica.v.7) and the means were displayed using the Duncan's multiple range tests $(p \leq 0.05)$. All the data are tabulated as the mean with the standard deviation.

\section{RESULTS AND DISCUSSION}

a. Effect of milling duration on Bran removal

The time taken for the rice kernels to undergo polishing had a significant effect on head rice yield, brokens and milling yield. The amount of bran removed with increasing milling time from 0 to 60 s revealed a significant difference among these cultivars. The cultivars Zag (20.70\%) and Teli zag (20.90\%) were found to depict the least content of bran removed during milling for the time period of 60 seconds as shown in Fig-1. Among the analyzed rice cultivars the Koshkari exhibited the highest percentage of bran removal at each milling interval of $10 \mathrm{~s}$ with value of $41.50 \%$ after the time period of $60 \mathrm{~s}$. This could be attributed to its grater thickness of the rice grains among the experimental rice cultivars. The amount of bran 
removed from the different rice cultivars at successive milling intervals depends upon variety, hardness, size and shape of rice kernels and the type of mill [9]. The amount of bran removed at each successive stage of milling with time was found to be higher than previous milling duration. The percentage of bran removed from the rice cultivars in the time interval of 0 to 30s showed sharp slope, but the slope was less after this time duration (30-60s). This relation between time and bran removal was found to be in accordance with the finding of of Lamberts et al. (2007) and Liu et al. (2009). The hardness of the bran layers had been reported by Lamberts et al. (2007) to increase from outer to inner layers, while the different fractions of endosperm were found to be of comparable hardness. In almost all the analysed rice cultivars about $9 \%$ of bran was found to be removed up to the time period of $15 \mathrm{~s}$, which had been validated to represent the bran fractions in rice kernels [3]. While the fractions removed after milling duration exceeding $15 \mathrm{~s}$ had been designated as endosperm. The fraction removed after $15 \mathrm{~s}$ with percentage between $9-15 \%$ had been designated as outer endoeperm and that fraction removed from $15-25 \%$ as middle endosperm [11].

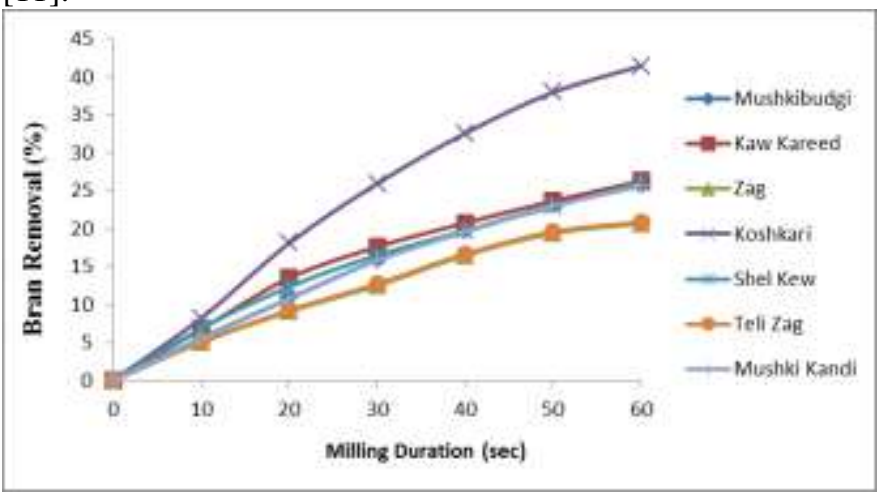

Figure 1. Effect of milling duration on Bran removal of rice cultivars

b. Effects of milling duration on protein content

The protein content in the rice grains were found to decrease significantly with respect to time of milling as shown in Table 1. The percentage of protein with milling duration depicted negative correlation, which indicated higher protein content could be retained by lowering the time period of milling. The milling time up to 60 seconds resulted in the higher loss of 31 $\%$ protein content in Mushki budgi fallowed Koshkari and Zag with $29 \%$ loss in protein content. The lowest loss in protein content after 60 s milling time was found in Teli zag $(21.13 \%)$. The results were found in accordance with the work of earlier researchers ([12], [11]. The lowest loss of protein content in pigmented rice cultivars upon milling could be due to higher content of protein in endosperm than in bran as validated previously by Lamberts et al. (2007) and Paiva et al. (2016). The major fractions of protein content $(84.2 \%)$ had been found to be concentrated in the outer endosperm and thus milling beyond the time period of bran removal could resulted in loss of protein as validated previously by Lamberts et al. (2007). Proteins in rice are mainly present in the bran and the removal of bran upon milling resulted in lowering of protein content [13]. The reduction in protein content with increasing milling duration further indicated its decrease in concentration from bran layer to endosperm. Milling of rice to higher degrees had been found to result in the loss of essential amino acids like lysine, tartaric and glutamic acid that are mainly responsible for the pleasant flavour and taste in cooked rice [14]. The fraction of milled rice mainly the polished fraction that contains high protein content is mostly the part of the outer endosperm of rice kernels [11].

Table 1. Effects of milling duration on protein content $(\%)$ of rice cultivars

\begin{tabular}{|c|c|c|c|c|c|c|c|}
\hline \multirow{2}{*}{ Cultivars } & \multicolumn{7}{|c|}{ Time duration (s) } \\
\hline & $\mathbf{0}$ & 10 & 20 & 30 & 40 & 50 & 60 \\
\hline $\begin{array}{l}\text { Mushki } \\
\text { Budgi }\end{array}$ & $7.57 \pm 0.05^{\mathrm{d}}$ & $7.35 \pm 0.03^{\mathrm{d}}$ & $6.95 \pm 0.03^{\mathrm{d}}$ & $6.27 \pm 0.05^{\mathrm{d}}$ & $5.93 \pm 0.03^{\mathrm{d}}$ & $5.41 \pm 0.05^{\mathrm{d}}$ & $5.21 \pm 0.03^{\mathrm{d}}$ \\
\hline Koshkari & $7.15 \pm 0.02^{\mathrm{e}}$ & $6.82 \pm 0.05^{\mathrm{e}}$ & $6.23 \pm 0.05^{\mathrm{e}}$ & $5.87 \pm 0.02^{\mathrm{e}}$ & $5.53 \pm 0.05^{\mathrm{e}}$ & $5.28 \pm 0.03^{c}$ & $5.03 \pm 0.05^{\mathrm{e}}$ \\
\hline Zag & $8.55 \pm 0.03^{b}$ & $7.73 \pm 0.05^{\mathrm{c}}$ & $7.25 \pm 0.03^{c}$ & $6.92 \pm 0.05^{\mathrm{c}}$ & $6.47 \pm 0.03^{\mathrm{c}}$ & $6.17 \pm 0.05^{\mathrm{c}}$ & $6.07 \pm 0.05^{\mathrm{c}}$ \\
\hline $\begin{array}{l}\text { Mushki } \\
\text { Tujan }\end{array}$ & $7.25 \pm 0.05^{\mathrm{e}}$ & $6.91 \pm 0.03^{\mathrm{e}}$ & $6.31 \pm 0.05^{\mathrm{c}}$ & $6.03 \pm 0.03^{\mathrm{e}}$ & $5.91 \pm 0.05^{\mathrm{d}}$ & $5.43 \pm 0.05^{\mathrm{d}}$ & $5.23 \pm 0.03^{\mathrm{d}}$ \\
\hline Kaw kareed & $8.75 \pm 0.05^{\mathrm{a}}$ & $8.13 \pm 0.05^{b}$ & $7.83 \pm 0.15^{b}$ & $7.24 \pm 0.05^{\mathrm{b}}$ & $6.97 \pm 0.03^{b}$ & $6.45 \pm 0.03^{b}$ & $6.27 \pm 0.02^{\mathrm{b}}$ \\
\hline Teli Zag & $8.85 \pm 0.03^{\mathrm{a}}$ & $8.64 \pm 0.03^{\mathrm{a}}$ & $8.15 \pm 0.05^{\mathrm{a}}$ & $7.88 \pm 0.05^{\mathrm{a}}$ & $7.35 \pm 0.05^{\mathrm{a}}$ & $7.12 \pm 0.15^{\mathrm{a}}$ & $6.98 \pm 0.05^{\mathrm{a}}$ \\
\hline Shel kew & $8.35 \pm 0.05^{\mathrm{c}}$ & $7.87 \pm 0.03^{c}$ & $7.23 \pm 0.05^{\mathrm{c}}$ & $6.95 \pm 0.03^{c}$ & $6.47 \pm 0.15^{\mathrm{c}}$ & $6.25 \pm 0.05^{\mathrm{c}}$ & $6.03 \pm 0.03^{c}$ \\
\hline
\end{tabular}

c. Effects of milling duration on fat content

Values are expressed as mean \pm SD. Means having different letters within the same column differ significantly $(\mathrm{p} \leq 0.05)$.
The effects of milling duration on the fat content are shown in Table 2. The percentage loss in fat content at successive 
milling interval differed significantly in different rice cultivars. It is clearly discernable that with increasing the milling time, the fat content in the analysed rice cultivars were found to decrease. The difference in fat percentage with milling time from 0 to 60s was found higher in Mushki Budgi $(1.15 \%)$ fallowed by Muski Tujan $(0.97 \%)$, while the lowest differences were found in Koshkari $(0.53 \%)$. These results are in agreement with the reported values of Juliano [15] who also revealed the decrease in fat content with successive stages of milling. The decline in fat content with increase in milling time could be linked to the removal of bran layer from the rice cultivars where most of the fat are concentrated ([16], [12]). The decrease in fat content of brown rice with milling had been reported by Monks et al. (2013) and in black and red rice by Paiva et al. (2016). The increase in lightness of the rice kernels with milling time could be attributed to the reduction in fat content that are held responsible for causing yellowish colour [17].

Table 2. Effects of milling duration on fat content (\%) of rice cultivars

\begin{tabular}{cc|c|c|c|c|c|c}
\hline \multirow{2}{*}{ Cultivars } & \multicolumn{7}{c}{ Time duration (s) } \\
\cline { 2 - 8 } & $\mathbf{0}$ & $\mathbf{1 0}$ & $\mathbf{2 0}$ & $\mathbf{3 0}$ & $\mathbf{4 0}$ & $\mathbf{5 0}$ & $\mathbf{6 0}$ \\
\hline Mushki Budgi & $1.77 \pm 0.04^{\mathrm{a}}$ & $1.53 \pm 0.05^{\mathrm{a}}$ & $1.31 \pm 0.03^{\mathrm{a}}$ & $1.16 \pm 0.02^{\mathrm{a}}$ & $0.92 \pm 0.05^{\mathrm{a}}$ & $0.76 \pm 0.05^{\mathrm{a}}$ & $0.62 \pm 0.05^{\mathrm{a}}$ \\
Koshkari & $0.60 \pm 0.02^{\mathrm{d}}$ & $0.45 \pm 0.05^{\mathrm{a}}$ & $0.34 \pm 0.05^{\mathrm{d}}$ & $0.25 \pm 0.05^{\mathrm{d}}$ & $0.18 \pm 0.04^{\mathrm{d}}$ & $0.10 \pm 0.02^{\mathrm{c}}$ & $0.07 \pm 0.03^{\mathrm{c}}$ \\
Zag & $1.55 \pm 0.03^{\mathrm{b}}$ & $1.32 \pm 0.03^{\mathrm{b}}$ & $1.18 \pm 0.05^{\mathrm{b}}$ & $1.03 \pm 0.05^{\mathrm{b}}$ & $0.87 \pm 0.02^{\mathrm{a}}$ & $0.75 \pm 0.05^{\mathrm{a}}$ & $0.63 \pm 0.05^{\mathrm{a}}$ \\
Mushki Tujan & $1.57 \pm 0.05^{\mathrm{b}}$ & $1.35 \pm 0.03^{\mathrm{b}}$ & $1.15 \pm 0.05^{\mathrm{b}}$ & $1.01 \pm 0.03^{\mathrm{b}}$ & $0.83 \pm 0.03^{\mathrm{b}}$ & $0.74 \pm 0.03^{\mathrm{a}}$ & $0.60 \pm 0.03^{\mathrm{a}}$ \\
Kaw kareed & $1.28 \pm 0.05^{\mathrm{c}}$ & $1.08 \pm 0.04^{\mathrm{c}}$ & $0.92 \pm 0.05^{\mathrm{c}}$ & $0.78 \pm 0.05^{\mathrm{c}}$ & $0.57 \pm 0.05^{\mathrm{c}}$ & $0.42 \pm 0.05^{\mathrm{b}}$ & $0.34 \pm 0.04^{\mathrm{b}}$ \\
Teli Zag & $0.63 \pm 0.03^{\mathrm{d}}$ & $0.48 \pm 0.03^{\mathrm{a}}$ & $0.37 \pm 0.05^{\mathrm{d}}$ & $0.28 \pm 0.02^{\mathrm{d}}$ & $0.17 \pm 0.04^{\mathrm{d}}$ & $0.10 \pm 0.03^{\mathrm{c}}$ & $0.07 \pm 0.05^{\mathrm{c}}$ \\
Shel kew & $1.57 \pm 0.05^{\mathrm{b}}$ & $1.38 \pm 0.05^{\mathrm{b}}$ & $1.18 \pm 0.03^{\mathrm{b}}$ & $1.01 \pm 0.05^{\mathrm{b}}$ & $0.88 \pm 0.03^{\mathrm{a}}$ & $0.73 \pm 0.05^{\mathrm{a}}$ & $0.61 \pm 0.02^{\mathrm{a}}$ \\
\hline
\end{tabular}

Values are expressed as mean \pm SD. Means having different letters within the same column differ significantly $(p \leq 0.05)$.

\section{d. Effects of milling duration on carbohydrate content}

The variation in carbohydrate content of the rice cultivars at different milling durations showed a significant difference as shown in Table 3. The carbohydrate content of these rice cultivars at each successive stage of milling were found to increase with Mushki budgi depicted the highest rise in percentage in carbohydrate content $(3.61 \%)$ after 60 s milling. The lowest loss in carbohydrate content among the cultivars after 60s milling was found to be lowest in Mushki Tujan
$(0.56 \%)$. The increase in carbohydrate content with increasing the degree of milling in rice kernels had been revealed by Payakapol et al. (2011). Carbohydrate are present mainly as starch in rice kernels that is concentrated in the endosperm and the milling of rice up to various stages increases the starch content due to the removal of the bran and germ from the rice kernels [13]. Carbohydrate content in rice could be measured either as whole or as amount of amylose content. Therefore the amylose content increases with increasing the time period of milling as confirmed earlier by Sidhu et al. (1975). The carbohydrates had been reported in determining the sweetness of rice [20].

Table 3. Effects of milling duration on carbohydrate content (\%) of rice cultivars

\begin{tabular}{cccccccc}
\hline \multirow{2}{*}{ Cultivars } & $\mathbf{0}$ Time duration (s) \\
\cline { 2 - 7 } & $\mathbf{0}$ & $\mathbf{1 0}$ & $\mathbf{2 0}$ & $\mathbf{3 0}$ & $\mathbf{4 0}$ & $\mathbf{5 0}$ & $\mathbf{6 0}$ \\
\hline Mushki Budgi & $77.58 \pm 0.26^{\mathrm{b}}$ & $77.73 \pm 0.21^{\mathrm{b}}$ & $77.85 \pm 0.23^{\mathrm{b}}$ & $77.93 \pm 0.15^{\mathrm{b}}$ & $80.18 \pm 0.15^{\mathrm{a}}$ & $80.27 \pm 0.26^{\mathrm{a}}$ & $80.38 \pm 0.15^{\mathrm{a}}$ \\
Koshkari & $79.38 \pm 0.23^{\mathrm{a}}$ & $79.48 \pm 0.23^{\mathrm{a}}$ & $79.62 \pm 0.15^{\mathrm{a}}$ & $79.86 \pm 0.15^{\mathrm{a}}$ & $79.95 \pm 0.23^{\mathrm{b}}$ & $80.13 \pm 0.21^{\mathrm{a}}$ & $80.35 \pm 0.23^{\mathrm{a}}$ \\
Zag & $74.76 \pm 0.2^{\mathrm{f}}$ & $74.85 \pm 0.21^{\mathrm{e}}$ & $74.93 \pm 0.21^{\mathrm{e}}$ & $75.14 \pm 0.23^{\mathrm{e}}$ & $75.27 \pm 0.15^{\mathrm{e}}$ & $75.38 \pm 0.23^{\mathrm{d}}$ & $75.52 \pm 0.21^{\mathrm{d}}$ \\
Mushki Tujan & $74.84 \pm 0.21^{\mathrm{e}}$ & $74.92 \pm 0.23^{\mathrm{e}}$ & $75.17 \pm 0.23^{\mathrm{e}}$ & $75.28 \pm 0.21^{\mathrm{e}}$ & $75.37 \pm 0.15^{\mathrm{e}}$ & $75.46 \pm 0.21^{\mathrm{d}}$ & $75.26 \pm 0.23^{\mathrm{d}}$ \\
Kaw kareed & $75.49 \pm 0.15^{\mathrm{d}}$ & $75.57 \pm 0.26^{\mathrm{d}}$ & $75.78 \pm 0.15^{\mathrm{d}}$ & $75.93 \pm 0.15^{\mathrm{d}}$ & $76.15 \pm 0.21^{\mathrm{d}}$ & $76.32 \pm 0.15^{\mathrm{c}}$ & $76.53 \pm 0.21^{\mathrm{c}}$
\end{tabular}


International Journal of Engineering Applied Sciences and Technology, 2019

Vol. 4, Issue 3, ISSN No. 2455-2143, Pages 294-301

Published Online July 2019 in IJEAST (http://www.ijeast.com)

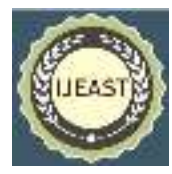

\begin{tabular}{cccccccc} 
Teli Zag & $76.61 \pm 0.25^{\mathrm{c}}$ & $76.78 \pm 0.26^{\mathrm{c}}$ & $76.86 \pm 0.26^{\mathrm{c}}$ & $76.95 \pm 0.26^{\mathrm{c}}$ & $77.17 \pm 0.26^{\mathrm{c}}$ & $77.28 \pm 0.21^{\mathrm{b}}$ & $77.41 \pm 0.15^{\mathrm{b}}$ \\
Shel kew & $74.40 \pm 0.2^{\mathrm{f}}$ & $74.62 \pm 0.15^{\mathrm{f}}$ & $74.73 \pm 0.26^{\mathrm{f}}$ & $74.87 \pm 0.26^{\mathrm{f}}$ & $74.96 \pm 0.21^{\mathrm{f}}$ & $75.17 \pm 0.15^{\mathrm{e}}$ & $75.32 \pm 0.23^{\mathrm{d}}$ \\
\hline
\end{tabular}

Values are expressed as mean \pm SD. Means having different letters within the same column differ significantly $(\mathrm{p} \leq 0.05)$.

\section{e. Effects of milling duration on ash content}

The effects of milling duration on ash content had been presented in Table 4 . The ash content of the rice cultivars were found to decrease with increasing the duration of milling. The greater loss in ash content with increasing the degree of milling was found in Mushki budgi (94.73\%) with its values ranging from 0.57 at starting point to $0.03 \%$ after $60 \mathrm{~s}$. However the red colored Zag $(55.23 \%)$ and the aromatic Mushki kandi $(53.14 \%)$ were found to exhibit the lowest loss in ash content with increasing the milling time. The ash content of the rice cultivars is an indicator of the minerals content present in it [21]. The bran layer of the rice contains the highest content of ash. The losses of minerals in rice upon milling had been reported to be up to $84.7 \%$ by Liu et al. (2009). The reduction in ash content in rice varieties with increasing the time of milling was also confirmed by Lamberts et al. (2007) and Paiva et al. (2014). These findings validated that the decrease in ash content in rice cultivars upon milling could be attributed to the removal of outer bran layers. The highest concentration of minerals at about $61 \%$ in the bran layer of pigmented rice had been confirmed earlier by Lamberts et al. (2007) and Singh et al. (2000). The variations in ash content among different rice cultivars could be attributed to different degrees of bran removal rich in ash content after each milling time.

Table 4. Effects of milling duration on Ash content (\%)of rice cultivars

\begin{tabular}{|c|c|c|c|c|c|c|c|}
\hline \multirow{2}{*}{ Cultivars } & \multicolumn{7}{|c|}{ Time duration (s) } \\
\hline & $\mathbf{0}$ & 10 & 20 & 30 & 40 & 50 & 60 \\
\hline Mushki Budgi & $0.57 \pm 0.05^{\mathrm{d}}$ & $0.38 \pm 0.03^{\mathrm{d}}$ & $0.23 \pm 0.05^{\mathrm{d}}$ & $0.18 \pm 0.03^{\mathrm{d}}$ & $0.10 \pm 0.05^{\mathrm{e}}$ & $0.07 \pm 0.05^{\mathrm{e}}$ & $0.03 \pm 0.05^{\mathrm{d}}$ \\
\hline Koshkari & $0.85 \pm 0.04^{\mathrm{c}}$ & $0.67 \pm 0.05^{\mathrm{c}}$ & $0.51 \pm 0.03^{\mathrm{c}}$ & $0.36 \pm 0.05^{\mathrm{c}}$ & $0.21 \pm 0.03^{\mathrm{e}}$ & $0.12 \pm 0.05^{\mathrm{d}}$ & $0.05 \pm 0.05^{\mathrm{d}}$ \\
\hline Zag & $1.61 \pm 0.05^{\mathrm{a}}$ & $1.43 \pm 0.05^{\mathrm{a}}$ & $1.28 \pm 0.05^{\mathrm{a}}$ & $1.14 \pm 0.05^{\mathrm{a}}$ & $1.04 \pm 0.05^{\mathrm{b}}$ & $0.86 \pm 0.05^{\mathrm{a}}$ & $0.72 \pm 0.03^{\mathrm{a}}$ \\
\hline Mushki Tujan & $1.75 \pm 0.03^{\mathrm{a}}$ & $1.54 \pm 0.03^{\mathrm{a}}$ & $1.37 \pm 0.05^{\mathrm{a}}$ & $1.25 \pm 0.03^{\mathrm{a}}$ & $1.13 \pm 0.03^{\mathrm{a}}$ & $0.95 \pm 0.03^{\mathrm{a}}$ & $0.82 \pm 0.05^{\mathrm{a}}$ \\
\hline Kaw kareed & $1.45 \pm 0.03^{\mathrm{b}}$ & $1.28 \pm 0.03^{\mathrm{b}}$ & $1.13 \pm 0.03^{\mathrm{ab}}$ & $1.05 \pm 0.05^{\mathrm{ab}}$ & $0.87 \pm 0.03^{\mathrm{c}}$ & $0.65 \pm 0.03^{b}$ & $0.47 \pm 0.03^{b}$ \\
\hline Teli Zag & $0.71 \pm 0.05^{\mathrm{c}}$ & $0.53 \pm 0.03^{c}$ & $0.48 \pm 0.05^{\mathrm{c}}$ & $0.37 \pm 0.03^{\mathrm{c}}$ & $0.23 \pm 0.05^{\mathrm{e}}$ & $0.18 \pm 0.05^{\mathrm{d}}$ & $0.08 \pm 0.03^{\mathrm{d}}$ \\
\hline Shel kew & $1.37 \pm 0.03^{\mathrm{b}}$ & $1.18 \pm 0.05^{b}$ & $1.08 \pm 0.03^{\mathrm{b}}$ & $0.88 \pm 0.03^{b}$ & $0.76 \pm 0.05^{\mathrm{d}}$ & $0.53 \pm 0.03^{c}$ & $0.37 \pm 0.05^{\mathrm{c}}$ \\
\hline
\end{tabular}

Values are expressed as mean \pm SD. Means having different letters within the same column differ significantly $(\mathrm{p} \leq 0.05)$.

\section{f. Effects of milling duration on elongation ratio of cooked rice}

The elongation ratio is an essential characteristic that gives an idea about the appearance of the cooked rice kernels. The rice kernels elongate lengthwise or breadth wise after cooking thereby giving finer or coarse appearance to it. The elongation ratio of the experimental rice cultivars were found to increase at each successive stage of milling interval. The highest elongation ratio calculated as difference between milling time of $0 \mathrm{~s}$ and $60 \mathrm{~s}$ were found in Zag and Shel kew with values of 0.9 as given in Table 5. The lowest elongation was found in
Mushki kandi (0.05) with its values ranging between 1.75 at 0 s to 1.80 at $60 \mathrm{~s}$. The cooked rice kernels having the property of elongation lengthwise are being preferred and are considered high quality rice than those which expand breadth wise [23]. The increase in elongation ratio after each, milling duration could be attributed to increase in carbohydrate or amylose content and decrease in fat content. The higher amylose content in milled rice takes up more water upon cooking thereby leading to increasing length of rice kernels [24]. The higher elongation ratio after each milling interval may be associated with the corresponding decrease in protein content as higher protein content pre-supposes higher gelatinisation temperature and tends to hinder cooking of rice [15]. 
International Journal of Engineering Applied Sciences and Technology, 2019

Vol. 4, Issue 3, ISSN No. 2455-2143, Pages 294-301

Published Online July 2019 in IJEAST (http://www.ijeast.com)

Table 5. Effects of milling duration on Elongation ratio of rice cultivars

\begin{tabular}{|c|c|c|c|c|c|c|c|}
\hline \multirow{2}{*}{ Cultivars } & \multicolumn{7}{|c|}{ Time duration (s) } \\
\hline & $\mathbf{0}$ & 10 & 20 & 30 & 40 & 50 & 60 \\
\hline Mushki Budgi & $1.94 \pm 0.06^{\mathrm{a}}$ & $1.94 \pm 0.05^{\mathrm{a}}$ & $1.95 \pm 0.05^{\mathrm{a}}$ & $1.97 \pm 0.05^{\mathrm{a}}$ & $1.98 \pm 0.02^{\mathrm{a}}$ & $1.99 \pm 0.05^{\mathrm{a}}$ & $2.00 \pm 0.05^{\mathrm{a}}$ \\
\hline Koshkari & $1.55 \pm 0.04^{\mathrm{d}}$ & $1.56 \pm 0.03^{\mathrm{c}}$ & $1.57 \pm 0.03^{\mathrm{d}}$ & $1.58 \pm 0.04^{\mathrm{d}}$ & $1.60 \pm 0.05^{\mathrm{c}}$ & $1.61 \pm 0.04^{\mathrm{c}}$ & $1.62 \pm 0.02^{\mathrm{c}}$ \\
\hline Zag & $1.43 \pm 0.03^{\mathrm{d}}$ & $1.45 \pm 0.05^{\mathrm{d}}$ & $1.46 \pm 0.05^{\mathrm{e}}$ & $1.48 \pm 0.05^{\mathrm{e}}$ & $1.49 \pm 0.04^{\mathrm{d}}$ & $1.51 \pm 0.05^{\mathrm{d}}$ & $1.52 \pm 0.05^{\mathrm{c}}$ \\
\hline Mushki Tujan & $1.75 \pm 0.23^{\mathrm{c}}$ & $1.76 \pm 0.04^{\mathrm{b}}$ & $1.76 \pm 0.04^{\mathrm{c}}$ & $1.77 \pm 0.03^{\mathrm{c}}$ & $1.77 \pm 0.03^{\mathrm{b}}$ & $1.78 \pm 0.03^{\mathrm{b}}$ & $1.80 \pm 0.05^{\mathrm{b}}$ \\
\hline Kaw kareed & $1.46 \pm 0.08^{\mathrm{d}}$ & $1.45 \pm 0.02^{\mathrm{d}}$ & $1.46 \pm 0.05^{\mathrm{e}}$ & $1.48 \pm 0.05^{\mathrm{e}}$ & $1.49 \pm 0.05^{\mathrm{d}}$ & $1.50 \pm 0.05^{\mathrm{d}}$ & $1.52 \pm 0.03^{\mathrm{C}}$ \\
\hline Teli Zag & $1.83 \pm 0.05^{\mathrm{b}}$ & $1.84 \pm 0.03^{\mathrm{a}}$ & $1.85 \pm 0.03^{\mathrm{b}}$ & $1.87 \pm 0.02^{\mathrm{b}}$ & $1.87 \pm 0.05^{\mathrm{b}}$ & $1.88 \pm 0.03^{b}$ & $1.90 \pm 0.04^{\mathrm{a}}$ \\
\hline Shel kew & $1.84 \pm 0.08^{\mathrm{b}}$ & $1.86 \pm 0.05^{\mathrm{a}}$ & $1.87 \pm 0.05^{\mathrm{b}}$ & $1.88 \pm 0.03^{\mathrm{b}}$ & $1.90 \pm 0.02^{\mathrm{a}}$ & $1.91 \pm 0.05^{\mathrm{a}}$ & $1.93 \pm 0.05^{\mathrm{a}}$ \\
\hline
\end{tabular}

Values are expressed as mean \pm SD. Means having different letters within the same column differ significantly $(\mathrm{p} \leq 0.05)$.

\section{g. Effects of milling duration on solids in gruel loss of cooked rice}

The solids released during cooking of rice in the gruel had been found to increase with increasing the milling time as shown in Fig 2. It had been reported by several researchers that processing of rice during milling leading to polished rice are highly vulnerable to solids loss in gruel than unmilled rice ([25]; [17]. The differences in solids loss in gruel at the two extreme milling time in the analysed rice cultivars did not reveal a significant difference. Almost all cultivars depicted the difference in solids released at 0 and 60s milling time to be 0.15 except Koshkar and Teli zag with values calculated as 0.14 . The increase in solids loss at each milling stage could be due to bursting of the rice kernels upon cooking, as the increase in carbohydrate content at each successive milling stage resulted in greater absorption of water. The greater the carbohydrate (starch) expands in rice, the higher are the rice grains prone to leaching out into the cooking water [26]. The higher solids loss in gruel after each milling duration could be due to more contact of surface area of rice kernels with the water as the elongation ratio is more in successive milled rice. Such a positive correlation had been reported previously by Usha et al. (2012).

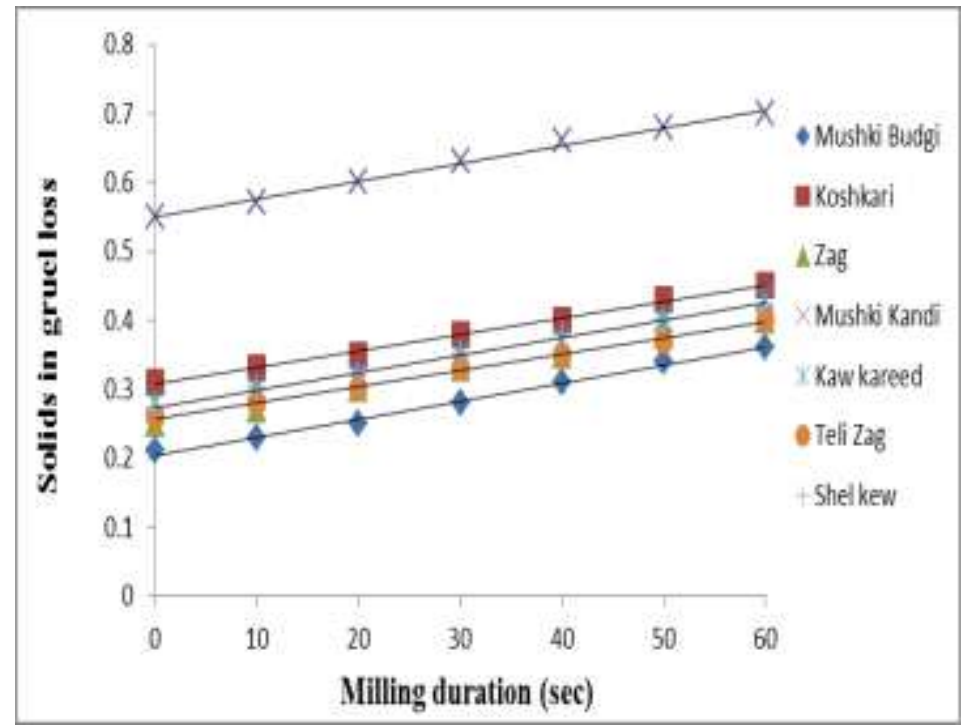

Figure 2. Effect of milling duration on solids in gruel loss of rice cultivars

\section{ETHICAL STATEMENTS}

Conflict of Interest: The corresponding author and all of the authors declare that they have no conflict of interest and approved in submitting this manuscript.

Ethical Review: This is to state that this study does not involve any human or animal testing.

Informed Consent: This is to state that the written informed consent was obtained from all study participants.

\section{CONCLUSION}

This research was done to investigate the effect of milling time from 0 to 60 seconds with interval of 10 seconds on the percentage of bran removal and its correlation with nutritional composition and cooking characteristics of Traditional Pigmented and aromatic rice cultivars. Among the analyzed rice cultivars the Koshkari exhibited the highest percentage of bran removal at each milling interval of $10 \mathrm{~s}$ that 


\section{International Journal of Engineering Applied Sciences and Technology, 2019 Vol. 4, Issue 3, ISSN No. 2455-2143, Pages 294-301 \\ Published Online July 2019 in IJEAST (http://www.ijeast.com)}

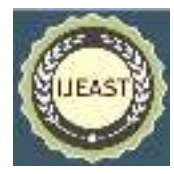

could be attributed to the greater thickness of the rice grains among the experimental rice cultivars. The milling time up to 60 seconds resulted in the higher loss of $31 \%$ protein content in Mushki budgi fallowed Koshkari and Zag with $29 \%$ loss in protein content. The red colored Zag and the aromatic Mushki kandi were found to exhibit the lowest loss in ash content with increasing the milling time. The higher solids loss in gruel after each milling duration could be due to more contact of surface area of rice kernels with the water as the elongation ratio is more in successive milled rice. The research would be useful in enhancing the regular monitoring of milling operation in an objective manner so that the desired properties are achieved as per specification of the final desired product.

\section{ACKNOWLEDGEMENT}

The author is thankful to the SKAUST (Khudwani breeding centre), Kashmir for providing these rice cultivars for research purposes and to the TEQIP-II funding agency for providing the funds to carry on the projects related to research purposes.

\section{REFERENCES}

1. Chen H., \& Siebenmorgen T. J. (1997). Effect of rice kernel thickness on degree of milling and associated optical measurements. Cereal Chemistry 74 (6): 821825.

2. Lamberts L, de Bie E, Vandeputte GE, Veraverbeke W. S, Derycke V, de Man W and Delcour J. A (2007). Effect of milling on colour and nutritional properties of rice. Food Chemistry 100(4): 1496-1503.

3. Wadsworth J. I, (1994). Rice: Science and technology (1st ed., pp. 139-176). New York: Marcel Dekker, Inc.

4.

Paiva F. F, Vanier N. L, Berrios J. D. J, Pinto

V. Z, Wood D, Williams T, Pan J, Elias M. C. (2016). Polishing and parboiling effect on the nutritional and technological properties of pigmented rice. Food Chemistry 191: 105-112.

5. Mohapatra D and Bal S. (2001). Wear of rice in an abrasive milling operation, part2: Prediction of bulk temperature rise. Bio-systems engineering 89: 101-8.

6. Ghadge P. N and Prasad K. (2012). Some physical properties of rice kernels variety PR-106, Journal of Food Process Technology 3: 175.

7. Yadav B. K and Jindal V. K. (2007). Modelling changes in milled rice (Oryza sativa L.) kernel dimensions during soaking by image analysis. Journal of Food Engineering 80: 359-369.

8. AOAC International. (2000). Official Methods of Analysis, 17th Ed., Washington DC.

9. Singh N, Singh H, Kaur K and Bakshi M. S. (2000). Relationship between the degree of milling, ash distribution pattern and conductivity in brown rice. Food Chemistry 69: 147-15.
10. Liu K, Cao X, Bai Q, Wen $\mathrm{H}$ and $\mathrm{Gu} Z$. (2009). Relationships between physical properties of brown rice and degree of milling and loss of selenium. Journal of Food Engineering 94 (1): 69-74.

11. Resurreccion A. P, Juliano B. O and Tanaka Y. (1979). Nutrient content and distribution in milling fractions of rice grain. Journal of the Science of Food and Agriculture 30: 475-481.

12. Itani $\mathrm{T}$, Tamaki $\mathrm{M}$, Arai $\mathrm{E}$ and Horino $\mathrm{T}$. (2002). Distribution of amylose, nitrogen, and minerals in rice kernels with various characters. Journal of Agricultural and Food Chemistry 50: 5326-5332.

13. Dhillon S. B and Sodhi N. S. (2014). Effect of Degree of Milling (Dom) on Overall Quality of RiceReview. International Journal of Advanced Biotechnology and Research (IJBR) 5(3): 474-489.

14. Tran T. U, Suzuki K, Okadome H, Homma S and Ohtsubo K. (2004). Analysis of the tastes of brown rice and milled rice with different milling yields using a taste sensing system. Food Chemistry 88: 557-566.

15. Juliano B. O. (1985). Rice chemistry and technology. 2nd edition, American Association of Cereal Chemists.

16. Frei M and Becker K. (2003). Studies on the in vitro starch digestibility and the glycemic index of six different indigenous rice cultivars from the philippines. Food Chemistry 83: 395-402.

17. Monks J. L. F, Vanier N. L, Casaril J, Berto R. M, de Oliveira M, Gomes C. B, de Carvalho M. P, Dias A. R. G and Elias M. C. (2013). Effects of milling on proximate composition, folic acid, fatty acids and technological properties of rice. Journal of Food Composition and Analysis 30(2): 73-79.

18. Payakapol L, Moongngarm A, Daomukda N and Noisuwan A. (2011). Influence of Degree of Milling on Chemical Compositions and Physicochemical Properties of Jasmine Rice. 2010 International Conference on Biology, Environment and Chemistry. IACSIT Press, Singapore.

19. Sidhu S. J, Gill M. S and Bains S. G. (1975). Milling of paddy in relation to yield and quality of rice of different Indian varieties. Journal of Agricultural and Food Chemistry 23: 1183-1185.

20. Saikusa T, Horino T and Mori Y. (1994). Distribution of free amino acids in the rice kernel and kernel fractions and the effect of water soaking on the distribution. Journal of Agricultural and Food Chemistry 42: 1122-1125.

21. Oko A. O and Ugwu S. I. (2011). The proximate and mineral compositions of five major rice varieties in Abakaliki, South-Eastern Nigeria. International Journal of Plant Physiology and Biochemistry 3(2). pp. 25-27. 
International Journal of Engineering Applied Sciences and Technology, 2019

Vol. 4, Issue 3, ISSN No. 2455-2143, Pages 294-301

Published Online July 2019 in IJEAST (http://www.ijeast.com)

22.

Paiva F. F, Vanier N. L, Berrios J.D.J, Pan J, de Almeida, Villanova F, Takeoka G and Elias M. C. (2014). Physicochemical and nutritional properties of pigmented rice subjected to different degrees of milling. Journal of Food Composition and Analysis 35(1): 10-17.

23.

Danbaba N, Anounye J.

C, Gana A.S, Abo M.E and Ukwungwu M.N. (2011). Grain quality characteristics of Ofada rice (Oryza sativa L.): Cooking and eating quality. International Food Research Journal 18: 629-634.

24. Asghar S, Anjum F. M, Amir R. M and Khan M. A. (2012). Cooking and eating characteristics of Rice (Oryza sativa L). Pakistan Journal of Food Sciences 22: 128-132.

25. Juliano B. Q and Pascual C. G. (1980). Quality characteristics of milled rice grown in different countries. The international rice research institute., Manila, Philippies IRPS No. 48,

26. Juliano B. O. (1971). A simplified assay for milled rice amylose. Cereal Science Today 16: 334-338.

27. Usha R, Menon L, Gomathy G, Parimala C and Rajeshwari R. (2012). Quality analysis of indigenous organic Asian Indian rice variety - Salem Samba. Indian Journal of Traditional Knowledge 11: 114-122. 